Témoigner Témoigner. Entre histoire et mémoire

Getuigen Revue pluridisciplinaire de la Fondation Auschwitz

$122 \mid 2016$

Révisionisme et négationisme

\title{
Oren Baruch Stier, Holocaust Icons. Symbolizing the Shoah in History and Memory
}

\section{Sayma Khan}

\section{Q OpenEdition \\ 1 Journals}

\section{Electronic version}

URL: https://journals.openedition.org/temoigner/4853

DOI: 10.4000/temoigner.4853

ISSN: 2506-6390

Publisher:

Éditions du Centre d'études et de documentation Mémoire d'Auschwitz, Éditions Kimé

\section{Printed version}

Date of publication: 2 May 2016

Number of pages: 165-166

ISSN: 2031-4183

\section{Electronic reference}

Sayma Khan, "Oren Baruch Stier, Holocaust Icons. Symbolizing the Shoah in History and Memory",

Témoigner. Entre histoire et mémoire [Online], 122 | 2016, Online since 30 September 2021, connection

on 07 January 2022. URL: http://journals.openedition.org/temoigner/4853 ; DOI: https://doi.org/

10.4000/temoigner.4853

This text was automatically generated on 7 January 2022.

Tous droits réservés 


\title{
Oren Baruch Stier, Holocaust Icons. Symbolizing the Shoah in History and Memory
}

\author{
Sayma Khan
}

\section{REFERENCES}

Oren Baruch Stier, Holocaust Icons. Symbolizing the Shoah in History and Memory, Rutgers

University Press, 2015, 224 p.

1 Anne Frank... railway cars... “Arbeit Macht Frei”... six million: that all these four terms are in some way related to the Holocaust and not merely arbitrarily put together, should be more or less self-understood. Oren Baruch Stier views them as Holocaust icons. Keeping in mind the original usage of the term "icon", which refers to an image or object that evokes "contemplation and veneration" (10), it is remarkable how the event of the Holocaust has given way to the "iconization" of objects that are not directly connected to religious motives. If the icons studied in the book vary in form literary, material, linguistic, numeric -, they all metonymically stand for the Holocaust itself and, as a part of a larger memorialization process, allow us to socially engage with the historical event.

2 The engagement with the Holocaust by means of icons facilitates the perspective of the spectators, rather than merely that of the witnesses. As Stier argues, the repetitive usage of these icons in memorial and museum settings bestows them with a symbolic power that creates "public meanings and perceptions of the Holocaust" (3). By communicating the representational, commemorative and functional meanings of the Holocaust, icons can effectively form a hinge point between past and present. A short examination of two icons chosen by Stier - namely railcars and Anne Frank - should suffice here to provide an insight into how relics, artifacts and / or narratives related to the Holocaust powerfully transmit knowledge of the event. 
3 The railcars often exhibited in Holocaust museums are primarily material artifacts belonging to a particular historical era. Their museological importance lies in their conveyance of "the material trace of authentic experience" (35), so in their embodiment of the deportation experience. According to the author, they are to be viewed as "icons of modern, industrialized mass murder, an artifact instrumental in the processing of human beings into commodities" (37). Railcars as such are not representative of mass murder, of course. However, their placement in Holocaust museums such as the Dallas Holocaust Museum (D H M), the United States Holocaust Memorial Museum (U S H M M, Washington), the Florida Holocaust Museum (F H M) and Yad Vashem (Jerusalem), and the specific memorial strategies attached to them, make them into icons. Whereas the railcar in D H M C, placed at the entrance, has an initiatory effect on the visitor, in U S H M M, it is situated "in the midst of the museum's chronological [... and] architectural narrative" (62) to produce an integrating effect. In F H M, the railcar is closed off and entrance is denied, thereby creating an exclusionary and ambivalent effect on the visitor. Finally, in Yad Vashem the railcar is uniquely placed "outside" the museum over a steep hill, unreachable and transformed into a monumental icon that "reinforces Israel's own mythologization of the Holocaust" (63). The different museological emplacement of the same feature - a railcar - suggests a specific mode of remembering in each museum, and reveals how, through repeated and concurrent usage, original artifacts can become icons.

Not only artifacts, but also persons like Anne Frank can acquire the status of Holocaust icons. Although her diary is a literary and material artifact, Anne's persona is equally iconized in the aftermath of the publication. Stier attributes her iconization "to her particular story, which is uniquely accessible and translatable to a global audience" (101). The transmission of her life-story in the form of diary entries not only communicates an authentic, highly individual and unique experience of the Holocaust. It also provides insight into the girl's quotidian life during the era, giving her diary a universal appeal. Another aspect of Anne Frank's iconization is the "plurimedial network", to use Astrid Erll's terminology, which surrounds the proliferation of her story. The diary is indeed supplemented with various pictures of her that have circulated world - wide: Anne's words together with her visual image constitute the icon. Again, we see how an icon originates by the continuous and repetitious remediation, and how it makes the Holocaust present today: the house where the girl hid with her family is the third most popular tourist attraction in Amsterdam, documentaries and feature films are made on her, and her life has been fictionalized many times - most notably in Philipp Roth's The Ghost Writer.

5 How Holocaust icons come into being, how they evolve in time and their power to communicate interpretations of the Holocaust, is what Stier tries to examine. The book offers four examples of Holocaust icons which "embody the presence of Shoah" (184) in contemporaneous times and thus keep its memory alive. 


\section{AUTHORS}

SAYMA KHAN

Goethe University Frankfurt 